\title{
Triple inguinal hernia: rare clinical presentation
}

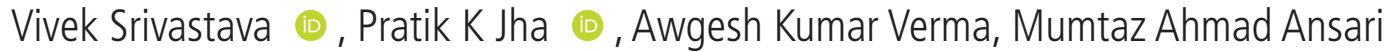

General Surgery, Banaras Hindu University Institute of Medical Sciences, Varanasi, Uttar Pradesh, India

\section{Correspondence to} Professor Vivek Srivastava; vivekims97@gmail.com

Accepted 11 October 2020

\section{DESCRIPTION}

A 64-year-old man presented with swelling in the bilateral inguinal region that increased on standing, straining and decreased spontaneously on lying down for last 1 year. It was associated with intermittent dull aching pain. He had no history suggestive of chronic cough, lower urinary tract symptoms, constipation and diabetes mellitus. On clinical evaluation, two distinct swellings were present in the right inguinal region and another one in the left inguinal region with expansile cough impulse (figure 1). A clinical diagnosis of bilateral reducible, non-complicated inguinal hernia was made with pantaloon hernia on the right side, which was confirmed by ultrasonography. The patient was planned for a bilateral total extraperitoneal mesh repair during which a direct as well as the indirect defect was seen on the right side (figure 2) and a direct defect on the left side. The postoperative course was uneventful.

Inguinal hernias are the most common type of primary hernias. Pantaloon hernia is a very rare variety of inguinal hernia with the presence of both direct and indirect sacs on either side of the inferior epigastric artery (IEA). It may also be referred to as saddle bag hernia, Romberg's hernia and dual hernia with a reported incidence of $5 \%$ in men and $1.6 \%$ in women. ${ }^{1}$ It is clinically seen almost exclusively in men and rarely presents with two distinct swellings in the inguinal region. Although a significant amount of work remains to elucidate the biologic nature of such hernias, current evidence suggests they have a multifactorial aetiology with both hereditary and environmental influences. The indirect variety is congenital in origin and may present in childhood or later, when, under the constant positive abdominal pressure, the deep inguinal ring and muscles are stretched. The direct variety is acquired and results from stretching and weakening of the abdominal wall just medial to the IEA. At times, a large indirect hernia may

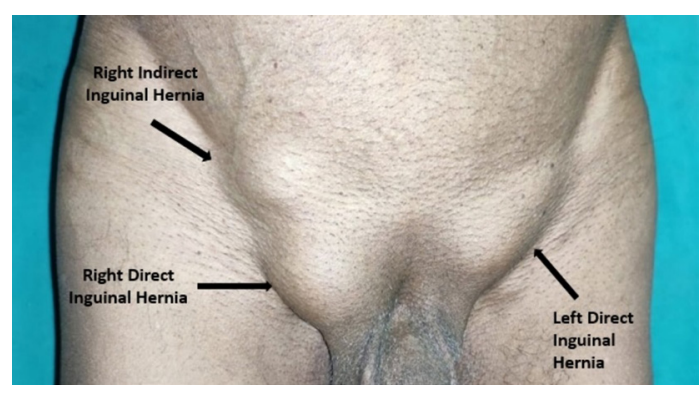

Figure 1 Right-sided pantaloon hernia with two distinct inguinal swellings and left-sided direct inguinal hernia.

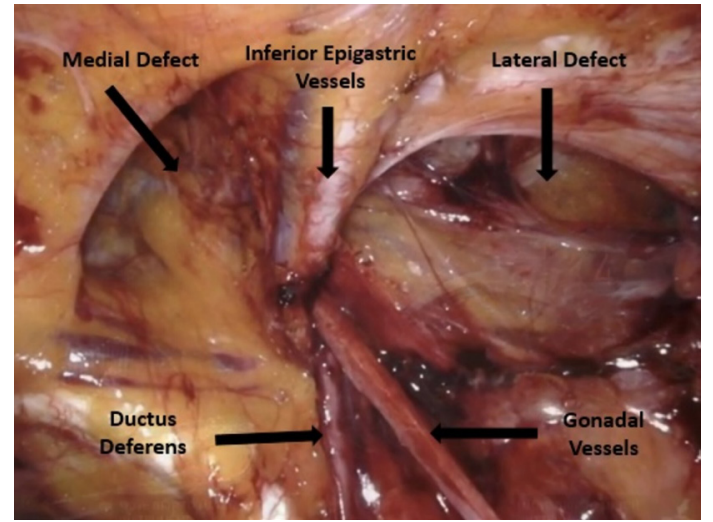

Figure 2 Preperitoneal view of the medial and lateral defects of the pantaloon hernia on the right side during total extraperitoneal mesh repair.

cause dilatation of the deep ring leading to weakening of the posterior wall that may cause bulging of the hernia sac on both sides of the IEA, leading to the formation of pantaloon hernia. ${ }^{12}$ Defective regulatory mechanism of hormones, peptides from the genitofemoral nerve and inadequate release of calcitonin gene-related peptide that have a role in testicular descent are some other causes attributed to the formation of aberrant hernia. ${ }^{2}$ However, in most of the cases, one of the hernias may remain occult and commonly presents as an obvious direct inguinal hernia and a small indirect type that cannot be demonstrated clinically. ${ }^{3}$ Diagnosis may be clinical or aided by ultrasonography, high-resolution CT and MRI in some cases. Nevertheless, it is generally identified during the course of surgery and maybe readily overlooked when one of the sacs is very small. ${ }^{3}$

The meticulous dissection of inguinal canal and identification of the inguinal structures are of utmost importance in hernia surgery. Misidentification, incomplete ligation of the sac and a missed small indirect sac in saddle bag hernia are common causes of recurrence. ${ }^{4}$ The management, however, remains the same as for the repair of other inguinal hernias in adults and only involves adequate repair

\section{Patient's perspective}

I developed swellings in the bilateral groin and my doctor told me that I had a bilateral inguinal hernia. I was told that I needed surgical repair for the same and they explained to me the various available options. I finally underwent laparoscopic repair following which the bulge and pain have gone away. I am thankful for the care I received from my doctor and his team. 


\section{Learning points}

- Pantaloon hernia is an uncommon variety of inguinal hernia that may rarely present with two distinct inguinal swellings.

- Most of these hernias are identified intraoperatively.

- Misidentification, incomplete ligation of the sac and a missed small indirect sac of saddle bag hernia during surgery are the common causes of recurrence.

of both the defects. ${ }^{5}$ Both open and laparoscopic methods can be used depending on the individual case type and the patient. Non-mesh repairs are not recommended due to lesser evidence and more chances of recurrence. If surgical expertise for laparoscopy and cost constraints are present, open repair is preferred. ${ }^{6}$

\section{Twitter Pratik K Jha @pratikjha17}

Contributors VS, PKJ and MAA were involved in conception and design of the article. VS, PKJ and AKV drafted the manuscript. VS, PKJ and MAA were involved in editing and proofreading.
Funding The authors have not declared a specific grant for this research from any funding agency in the public, commercial or not-for-profit sectors.

Competing interests None declared.

Patient consent for publication Obtained.

Provenance and peer review Not commissioned; externally peer reviewed.

\section{ORCID iDs}

Vivek Srivastava http://orcid.org/0000-0003-0313-9895

Pratik K Jha http://orcid.org/0000-0002-8871-7430

\section{REFERENCES}

1 Chawla S. Inguinal hernia in females. Med J Armed Forces India 2001;57:306-8

2 Wani I, hernia Ddirect. Double direct hernia, triple indirect hernia, double pantaloon hernia (Jammu, Kashmir and Ladakh hernia) with anomalous inferior epigastric artey: case report. Int J Surg Case Rep 2019;60:42-5.

3 Choudhari R, Rachel VP, Gaikwad P. Pantallon hernia in a woman: a Straddling rarity. Asian J Case Rep Surg 2018;1:1-5.

4 Qvist G. Saddlebag hernia. Br J Surg 1977;64:442-4.

5 Jones RG, Livaditis I, Almond PS. An unexpected finding during an inguinal herniorrhaphy: report of an indirect hernia with two hernia sacs. J Pediatr Surg Case Rep 2013;1:331-2.

6 Pahwa HS, Kumar A, Agarwal P, et al. Current trends in laparoscopic groin hernia repair: a review. World J Clin Cases 2015;3:789-92.

Copyright 2020 BMJ Publishing Group. All rights reserved. For permission to reuse any of this content visit

https://www.bmj.com/company/products-services/rights-and-licensing/permissions/

BMJ Case Report Fellows may re-use this article for personal use and teaching without any further permission.

Become a Fellow of BMJ Case Reports today and you can:

- Submit as many cases as you like

- Enjoy fast sympathetic peer review and rapid publication of accepted articles

- Access all the published articles

- Re-use any of the published material for personal use and teaching without further permission

\section{Customer Service}

If you have any further queries about your subscription, please contact our customer services team on +44 (0) 2071111105 or via email at support@bmj.com.

Visit casereports.bmj.com for more articles like this and to become a Fellow 